\title{
Analisis Literasi Kimia Peserta Didik di SMAN 1 Batam pada Topik Hukum-Hukum Dasar Kimia dengan Model Rasch
}

\author{
Nyak Mutya Aulina Khairul Fajri ${ }^{1)}$, Eka Yusmaita ${ }^{2)}$ \\ ${ }^{1)}$ Program Studi Pendidikan Kimia Universitas Negeri Padang \\ ${ }^{2)}$ Dosen Program Studi Pendidikan Kimia Universitas Negeri Padang \\ ekayusmaita@fmipa.unp.ac.id
}

\begin{abstract}
This study aims to analyze the SMAN 1 Batam students' chemical literacy level on the fundamental chemical laws topic according to the scientific literacy framework adapted by Shwartz. This research is a quantitative study with a sample of 50 XI grade science students from SMAN 1 Batam. Data is obtained from a chemical literacy test on the fundamental chemical laws topic answered by students; the data is analyzed with the Rasch model. The results showed students with the highest ability have a true answer with explanations that unrelated to the text of the items and students with the lowest ability have a wrong or a blank answer. Thus, it was concluded, students with the highest ability have a conceptual scientific literacy level on the hardest item, meanwhile, students with the lowest ability categorized as scientific illiteracy.
\end{abstract}

Keywords : chemical literacy, fundamental chemical laws, Rasch model

This is an open access article distributed under the Creative Commons 4.0 Attribution License, which permits unrestricted use, distribution, and reproduction in any medium, provided the original work is properly cited. $\odot 2018$ by author and Universitas Negeri Padang.

\section{PENDAHULUAN}

Salah satu permasalahan pendidikan sains di Indonesia adalah rendahnya literasi sains peserta didik karena kurang diperhatikannya pemahaman konsep terhadap materi yang sudah diajarkan (Imansari dkk., 2018). Literasi sains dapat dilatih menggunakan instrumen tes yang mengharuskan peserta didik mengerjakan soal-soal dengan berpikir kritis (Muhammad dkk., 2018). Menurut Odja \& Payu (2017), pada umumnya peserta didik yang belum terbiasa mengerjakan tes keterampilan proses sains memiliki kemampuan literasi sains yang cenderung rendah.

Kimia merupakan salah satu pembelajaran sains yang dijadikan sebagai mata pelajaran peminatan matematika dan ilmu pengetahuan alam (MIPA) (Kemendikbud, 2018). Menurut Yakmaci-Guzel (2013), kimia merupakan pembelajaran yang konsepnya bersifat abstrak, sehingga sulit untuk dipahami. Sulitnya pemahaman konsep kimia dapat mempengaruhi kemampuan literasi kimia peserta didik, karena literasi kimia merupakan kemampuan seseorang dalam memahami dan menerapkan konsep dasar kimia dalam kehidupan sehari-hari secara tepat dan efektif (Thummathong \& Thathong, 2016).
Berdasarkan survei yang dilakukan terhadap 85 orang peserta didik kelas XI MIPA di SMAN 1 Batam tahun ajaran (TA) 2020/2021, diperoleh hasil 70 orang peserta didik menyatakan topik dalam pembelajaran kimia terhitung banyak, sehingga dibutuhkan usaha yang lebih besar dalam memahami konsep-konsep kimia.

Melalui hasil survei yang sama, rata-rata peserta didik menyatakan topik hukum-hukum dasar kimia merupakan pelajaran dasar kimia kelas X yang sulit untuk dipahami. Alasan tersebut diperkuat oleh penjelasan guru mata pelajaran kimia yang menyatakan bahwa: "Masih terdapat hasil ulangan harian peserta didik pada topik hukum-hukum dasar kimia yang berada dibawah kriteria ketuntasan minimal (KKM). Hal ini menunjukkan peserta didik masih belum benarbenar paham dengan konsep-konsep yang sudah disampaikan."

Berdasarkan penelitian yang dilakukan oleh Shwartz dkk., (2006), dikatakan bahwa, "Pembelajaran topik dasar pada kimia memberikan kontribusi yang penting pada tingkat literasi kimia peserta didik." Penjelasan tersebut menandakan pemahaman subjek survei yang masih kurang pada topik hukum-hukum dasar kimia dapat memengaruhi tingkat literasi kimia 
peserta didik. Oleh karena itu, suatu evaluasi perlu dilakukan agar diketahui tingkat literasi kimia peserta didik dalam topik hukum-hukum dasar kimia.

Menurut Thummathong \& Thathong (2016), agar literasi kimia peserta didik berkembang secara efektif, dibutuhkan instrumen asesmen literasi kimia untuk membantu pengajar dalam menilai literasi kimia dan mengevaluasi keefektifan pembelajaran yang dilakukan di dalam kelas. Evaluasi tersebut dapat dilakukan menggunakan suatu tes yang baik, yaitu tes yang telah diuji validitas dan reliabilitasnya (Furwana, 2019).

Penelitian pengembangan soal yang dapat mengukur kemampuan literasi kimia peserta didik dilakukan oleh Sartika \& Yusmaita (2020). Soal yang dikembangkan merupakan soal topik hukum-hukum dasar kimia. Berdasarkan hasil analisis data penelitian tersebut, disimpulkan instrumen yang dihasilkan memiliki validitas konten yang dikategorikan "valid" dengan nilai 0,88 dan reliabilitas tes yang dikategorikan "reliabel" dengan nilai sebesar 0,88 . Terdapat 12 butir soal yang dapat digunakan untuk mengukur literasi kimia peserta didik. Butir soal yang dikembangkan merupakan butir soal yang dikonstruksi menggunakan aspek-aspek literasi sains PISA meliputi: konten, konteks, high order learning skill (HOLS), dan sikap (OECD, 2015). Rubrik jawaban yang digunakan menggunakan kerangka literasi kimia yang diadaptasi oleh Shwartz dkk., (2006), di antaranya: 1) scientific illiteracy, peserta didik tidak mengetahui istilah dan konsep sains; 2) nominal scientific literacy, peserta didik mengetahui istilah sains, namun tidak dapat menjelaskan konsep dari istilah tersebut; 3) functional scientific literacy, peserta didik dapat menjelaskan suatu istilah sains, namun pemahamannya masih terbatas dan terdapat miskonsepsi; 4) conceptual scientific literacy, peserta didik mampu menjelaskan serta menghubungan konsep sains dengan konsep-konsep lainnya; dan 5) multidimensional scientific literacy, peserta didik mampu menghubungkan konsep sains serta memperoleh informasi sains melalui suatu teks, iklan, maupun bacaan.

Analisis literasi kimia peserta didik menggunakan butir soal berbasis literasi kimia dapat dilakukan menggunakan teori respon butir (Item Response Theory/IRT) yang disebut se-

Volume 5| Nomor 1|Mei 2021|Page 102-109 bagai model Rasch. Analisis tersebut dapat dilakukan menggunakan aplikasi Winsteps Rasch, di antaranya adalah person measure, person fit, person reliability, dan Wright map (Untary dkk., 2020).

\section{METODE PENELITIAN}

Penelitian ini dilakukan menggunakan desain penelitian deskriptif dengan pendekatan kuantitatif. Teknik analisis data menggunakan model Rasch untuk mengungkapkan tingkat literasi kimia peserta didik.

Subjek pada penelitian ini adalah peserta didik kelas XI MIPA di SMAN 1 Batam TA 2020/2021. Teknik sampling yang digunakan adalah simple random sampling yang disesuaikan dengan model Rasch, pada model Rasch jumlah sampel sebanyak 50 memiliki selang kepercayaan sebesar $99 \%$ (Sumintono \& Widhiarso, 2015).

Instrumen penelitian yang digunakan merupakan butir soal berbasis literasi kimia pada topik hukum-hukum dasar kimia yang dikembangkan oleh Sartika \& Yusmaita (2020). Instrumen tersebut tersusun atas 7 buah teks wacana yang terdiri atas 12 butir soal berbentuk essay. Teks wacana yang digunakan dalam instrumen tersebut antara lain obat mag, hematit, hujan asam, kafein, fotosintesis, pesawat, dan larutan gula.

Teks wacana pertama adalah obat mag, wacana tersebut berhubungan dengan konsep hukum kekekalan massa. Berdasarkan butir soal yang diberikan, peserta didik diharapkan dapat menentukan massa dari hydrotalcite yang bereaksi pada mekanisme obat mag serta menentukan jenis hukum dasar kimia yang diterapkan pada butir soal tersebut. Teks wacana kedua, hematit, berhubungan dengan konsep hukum perbandingan tetap. Peserta didik diharapkan untuk menentukan perbandingan massa besi dan oksigen dalam berbagai pembuatan bijih besi $\left(\mathrm{Fe}_{2} \mathrm{O}_{3}\right)$ serta menentukan jenis hukum dasar kimia yang diterapkan pada butir soal tersebut. Teks wacana ketiga, hujan asam, berhubungan dengan konsep hukum perbandingan berganda. Peserta didik diharapkan untuk menentukan perbandingan oksigen pada masing-masing senyawa $\mathrm{SO}_{2}$ dan $\mathrm{SO}_{3}$, serta menentukan jenis hukum dasar kimia yang diterapkan. Teks wacana keempat, kafein, berhubungan dengan konsep massa molekul relatif. Peserta didik diharapkan untuk menentukan massa molekul relatif kafein. Teks wacana 
kelima, fotosintesis, berhubungan dengan konsep persamaan reaksi kimia. Peserta didik diharapkan dapat menentukan massa suatu zat berdasarkan persamaan reaksi kimia yang belum setara. Teks wacana keenam, pesawat, berhubungan dengan konsep mol. Peserta didik diharapkan dapat menentukan massa molar $\mathrm{TiCl}_{4}$, mol titanium (Ti), dan jumlah atom titanium (Ti). Teks wacana ketujuh, larutan gula, berhubungan dengan konsep kadar zat dalam campuran. Peserta didik diharapkan dapat menentukan kadar gula dalam satuan konsentrasi ppm.

Berdasarkan Tabel 1, setiap teks wacana soal terdiri atas 1-3 butir soal, dimana skor maksimum setiap butir adalah 4 (multidimensional scientific literacy) dan skor minimum setiap butir adalah 0 (scientific illiteracy). Contohnya, pada teks wacana 1 yang terdiri atas 2 butir soal, skor maksimumnya adalah 8 .

Tabel 1. Skor Maksimum Tes Berdasarkan Multidimensional Scientific Literacy

\begin{tabular}{l|c|c|c|c|c|c|c}
\hline Teks wacana & 1 & 2 & 3 & 4 & 5 & 6 & 7 \\
\hline Jumlah butir soal & 2 & 2 & 2 & 1 & 1 & 3 & 2 \\
\hline Skor maks & 8 & 8 & 8 & 4 & 4 & 12 & 4 \\
\hline Total skor & \multicolumn{7}{|c}{48} \\
\hline
\end{tabular}

Teknik analisis data penelitian meliputi analisis deskripif dan analisis data kuantitatif berbantuan aplikasi Winsteps 4.7.0.0 yang meliputi:

1) Person measure, merupakan perkiraan kemampuan mendasar suatu individu berdasarkan kinerja individu tersebut pada sekumpulan item (butir soal) yang mengukur satu sifat laten (literasi kimia) (Bond \& Fox, 2015). Nilai "person measure" itu sendiri merupakan hasil konversi dari skor mentah yang tidak linear terhadap skala Rasch (logit) (Khine, 2020).

2) Person fit, merupakan analisis pemeriksaan pola skor sebenarnya terhadap pola skor yang diharapkan model (skor dengan jenis data interval dengan satuan logit) untuk menilai kebermaknaan skor pada suatu individu [dilaporkan dalam nilai MNSQ] (Boone dkk., 2014). Menurut Linacre, secara umum nilai infit dan outfit MNSQ suatu individu yang kurang dari 0,5 atau lebih dari 1,5 menandakan nilai person fit yang buruk (Khine, 2020).

3) Reliabilitas person, merupakan perkiraan penempatan individu jika terdapat sampel individu yang diberikan butir soal untuk mengukur konstruk yang sama (Bond \& Fox, 2015). Reliabilitas person dikatakan buruk (poor) apabila memiliki nilai $<0,67$; cukup (fair) apabila memiliki nilai antara rentang $0,67-0,80$; baik (good) apabila memiliki nilai antara rentang $0,81-0,90$; sangat baik (very good) apabila memiliki nilai antara rentang $0,91-0,94$; dan dikatakan istimewa (excellent) apabila memiliki nilai $>0,94$.

4) Wright map, merupakan suatu peta yang berisikan persebaran kemampuan person dan tingkat kesukaran item dalam skala yang sama (Lestari \& Samsudin, 2020). Skala logit merupakan skala pengukuran yang berbentuk interval, jarak antara setiap titik pada skala vertikalnya memiliki ukuran yang sama (Bond \& Fox, 2015). Wright map dapat mendeskripsikan tingkatan kinerja individu dalam tes tertentu berdasarkan item-item yang dapat atau tidak dapat dikerjakan (Khine, 2020).

Evaluasi yang dilakukan terhadap jawaban tes literasi kimia peserta didik dilakukan menggunakan rubrik yang telah dikembangkan oleh pengembang butir soal. Berdasarkan kerangka literasi sains, rubrik jawaban memiliki lima bagian, jika jawabannya benar dan dihubungkan dengan informasi yang terdapat pada teks wacana maka skor yang didapatkan adalah 4, apabila jawabannya benar namun tidak dihubungkan dengan informasi pada teks wacana maka skor yang didapatkan adalah 3, apabila jawabannya benar namun penjelasannya terbatas atau terdapat kesalahan konsep pada jawaban maka skor yang didapatkan adalah 2, apabila jawabannya benar namun tidak terdapat penjelasan jawaban maka skor yang didapatkan adalah 1 , apabila tidak ada jawaban atau jawaban yang diberikan salah maka skor yang didapatkan adalah 0 (lihat Tabel 2).

Tabel 2. Penilaian Skor pada Rubrik

\begin{tabular}{ll}
\hline Butir Soal & Skor Jawaban \\
\hline Obat mag & Salah (0) \\
(item 1) & Benar namun tidak terdapat penjelasan \\
& jawaban (1) \\
& Benar namun penjelasan jawaban masih \\
& terbatas atau terdapat miskonsepsi (2) \\
& Benar namun penjelasan jawaban tidak \\
& dihubungkan dengan teks wacana (3) \\
& Benar dan penjelasan jawaban dihub- \\
& ungkan dengan teks wacana (4) \\
\hline
\end{tabular}




\section{HASIL DAN PEMBAHASAN}

Setiap butir soal literasi kimia yang dikembangkan oleh Sartika \& Yusmaita (2020) memiliki rubrik jawaban dengan skor yang sesuai terhadap masing-masing deskripsi tingkat literasi kimia yang diadaptasi oleh Shwartz dkk., (2006). Persentase hasil skor tes literasi kimia peserta didik per butir soal hukum-hukum dasar kimia dapat dilihat pada Tabel $\mathbf{3}$.

Tabel 3. Persentase Skor Tes Literasi Kimia Peserta Didik

\begin{tabular}{lccccc}
\hline \multirow{2}{*}{ Butir Soal } & \multicolumn{5}{c}{ Persentase Skor (\%) } \\
& 0 & $\mathbf{1}$ & $\mathbf{2}$ & $\mathbf{3}$ & $\mathbf{4}$ \\
\hline Obat mag (i1) & 2 & 0 & 24 & 58 & 16 \\
\hline Obat mag (i2) & 2 & 18 & 70 & 0 & 10 \\
\hline Hematit (i3) & 0 & 0 & 4 & 56 & 40 \\
\hline Hematit (i4) & 10 & 16 & 50 & 14 & 10 \\
\hline Hujan asam (i5) & 4 & 0 & 40 & 54 & 2 \\
\hline Hujan asam (i6) & 4 & 40 & 34 & 16 & 6 \\
\hline Kafein (i7) & 2 & 0 & 2 & 56 & 40 \\
\hline Fotosintesis (i8) & 28 & 4 & 48 & 18 & 2 \\
\hline Pesawat (i9) & 22 & 0 & 8 & 28 & 4 \\
\hline Pesawat (i10) & 40 & 0 & 40 & 10 & 10 \\
\hline Pesawat (i11) & 40 & 2 & 52 & 6 & 0 \\
\hline Larutan gula (i12) & 46 & 2 & 22 & 4 & 26 \\
\hline
\end{tabular}

Melalui penjabaran hasil skor tes literasi kimia peserta didik, diketahui sebanyak $16,6 \%$ peserta didik mendapatkan skor 0; sebanyak $7 \%$ peserta didik mendapatkan skor 1; sebanyak $32,8 \%$ peserta didik mendapatkan skor 2; sebanyak $26,6 \%$ peserta didik mendapatkan skor 3 ; sebanyak $17 \%$ peserta didik mendapatkan skor 4. Dapat disimpulkan peserta didik kelas XI MIPA di SMAN 1 Batam mendominasi skor 2 pada tes literasi kimia.

Berikut ini merupakan contoh jawaban peserta didik terhadap butir soal berbasis literasi kimia pada topik hukum-hukum dasar kimia. Misalnya pada butir soal mengenai obat maag, salah satu sub pertanyaannya adalah: Berdasarkan jawaban yang diperoleh, hukum apa yang mendasari reaksi tersebut? Berikan alasan!

Beberapa jawaban peserta didik pada soal tersebut adalah sebagai berikut:
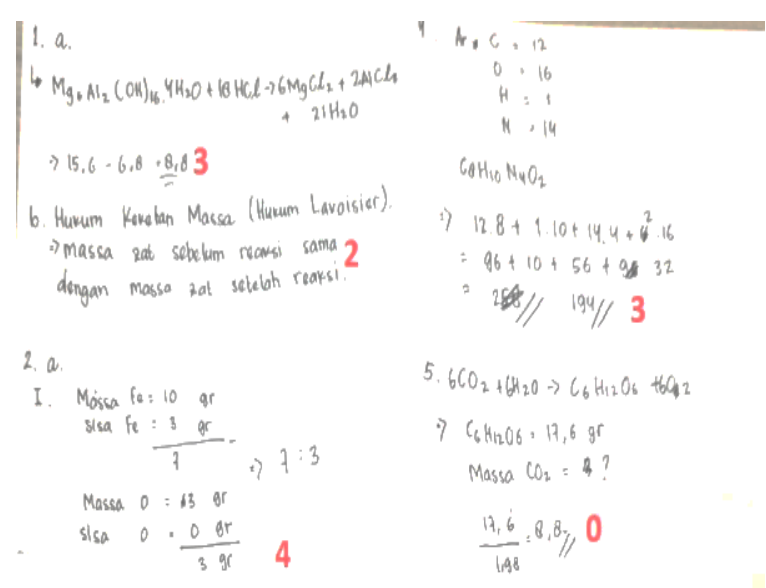

Gambar 1. Contoh Jawaban Peserta Didik dan Perolehan Skornya

Sementara itu, pada butir soal mengenai hematit, salah satu sub pertanyaannya adalah: Berdasarkan jawaban yang didapatkan, hukum apa yang mendasari informasi tersebut? Berikan alasan!

Beberapa jawaban peserta didik pada soal tersebut adalah sebagai berikut:

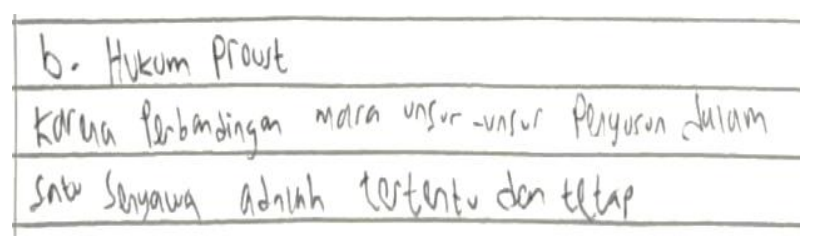

Gambar 2. Contoh Jawaban Peserta Didik

Berdasarkan jawaban-jawaban tersebut, diketahui kemampuan peserta didik dalam menjawab pertanyaan tersebut masih sangat terbatas dan terdapat miskonsepsi, sehingga sebagian besar peserta didik mendapatkan skor 2. Butir soal menuntut peserta didik untuk menjelaskan hukum dasar kimia yang mendasari wacana pada teks butir soal tersebut, namun hanya beberapa peserta didik yang menghubungkan penjelasan jawabannya dengan jawaban yang didapat dari butir soal yang sebelumnya ataupun dari informasi yang terdapat pada teks wacana.

Berdasarkan data hasil penelitian yang dianalisis menggunakan aplikasi model Rasch yaitu winisteps mengenai analisis literasi kimia peserta didik kelas XI MIPA di SMAN 1 Batam TA 2020/2021 pada topik hukum-hukum dasar kimia, didapati hasil sebagai berikut:

1) Person measure, berdasarkan rubrik jawaban butir soal berbasis literasi kimia, 
nilai skor mentah maksimum adalah 48. Bagi peserta didik yang mendapatkan skor mentah yang sempurna, dapat disimpulkan mereka memahami topik hukum-hukum dasar kimia pada tes literasi kimia tersebut dengan baik, namun seberapa jauh pemahaman peserta didik terhadap materi tersebut tidak diketahui. Begitu juga dengan peserta didik yang mendapatkan skor mentah 0, dapat diketahui bahwa peserta didik tidak mengetahui topik hukum-hukum dasar kimia pada tes tersebut, namun seberapa kurangnya pemahaman peserta didik terhadap topik tersebut juga tidak diketahui. Data hasil analisis person measure beberapa peserta didilk dapat dilihhat pada

Tabel 4.

Tabel 4. Data Analisis Person Measure

\begin{tabular}{ccc}
\hline Subjek & Skor mentah & Nilai measure \\
\hline 023P1 & $41 / 48$ & 2,47 \\
028L2 & $41 / 48$ & 2,47 \\
010L1 & $38 / 48$ & 1,85 \\
012L6 & $37 / 48$ & 1,66 \\
042P5 & $27 / 48$ & 0,18 \\
050L4 & $26 / 48$ & 0,7 \\
004P2 & $13 / 48$ & $-1,39$ \\
\hline
\end{tabular}

Menurut Khine (2020), semakin tinggi nilai person measure peserta didik pada suatu tes, menandakan peserta didik tersebut memiliki prestasi yang lebih tinggi. Adanya person measure peserta didik yang bernilai negatif disebabkan oleh rata-rata default (parameter tetap) item measure yang memiliki nilai logit 0,0 . Oleh karena itu, nilai negatif hanya isyarat bahwa peserta didik memiliki nilai person measure kurang dari mean tingkat kesulitan item. Adanya peserta didik yang mendapatkan nilai person measure negatif pada suatu tes tidak menandakan peserta didik tersebut memiliki kinerja yang sangat buruk dalam tes tersebut (Boone dkk., 2014).

Perbandingan kemampuan literasi kimia peserta didik dapat dilihat melalui nilai person measure. Subjek 010L1 dan 012L6 memiliki selisih nilai measure sebesar 0,19. Sementara itu, subjek 042P5 dan 050L4 memiliki selisih nilai measure sebesar 0,11 artinya, antara subjek 010L1 dan 012L6 serta subjek 042P5 dan 050L4 memiliki kemampuan literasi kimia yang berbeda. Melalui selisih nilai measure diketahui terdapat hampir dua kali lipat perbedaan tingkat literasi kimia antara subjek 010L1 dan 012L6 (0,19 logit) serta sulbjek 042P5 dan 050L4 (0,11 logit). Hal ini juga berlaku bagi subjek-subjek lainnya. Dapat disimpulkan nilai measure (logit) dapat dijadikan sebagai patokan dalam menentukan perbandingan kemampuan literasi kimia peserta didik kelas XI MIPA di SMAN 1 Batam. Semakin besar nilai logit maka semakin tinggi kemampuan literasi kimia peserta didilk (lihat

\section{Tabel 4).}

2) Person fit, data analisis nilai infit dan outfit MNSQ pada penelitian ini dapat dilihat pada Tabel 5.

Adanya nilai infit dan outfit MNSQ yang tidak sesuai menunjukkan $30 \%$ populasi peserta didik pada penelitian ini memiliki perilaku respon yang tidak sesuai. salah satu subjek dengan nilai infit dan outfit MNSQ yang tidak sesuai adalah subjek 021P1 dengan nilai infit MNSQ 2,42 dan nilai outfit MNSQ 3,46, kedua nilai tersebut membuktikan pola respon subjek tersebut pada tes literasi kimia tidak sesuai dengan ekspektasi model, dapat dilihat pada Gambar 1, pola jawaban subjek 021P1 mendapatkan poin 4 pada item 12 yang merupakan butir soal yang tergolong sulit, namun mendapatkan poin 2 pada item 3 yang merupakan butir soal termudah pada tes tersebut. Tabel 5. Person Infit dan Outfit MNSQ ZSTD

\begin{tabular}{cc}
\hline Infit dan Outfit MNSQ & Persentase \\
\hline$>1,5$ & $14 \%$ \\
$<0,5$ & $16 \%$ \\
\hline Mean & Nilai \\
\hline Infit MNSQ & 0,97 \\
Outfit MNSQ & 0,98 \\
Infit ZSTD & $-0,1$ \\
Outfit ZSTD & $-0,1$ \\
\hline
\end{tabular}

Nilai mean infit dan outfit MNSQ yang didapat adalah 0,97 dan 0,98. Kedua nilai tersebut berada dibawah 1, artinya data hasil penelitian yang dianalisis memiliki variasi data $22 \%$ lebih sedikit dibandingkan variasi data yang diprediksi oleh model Rasch (Bond \& Fox, 2015). Jumlah variasi data yang sedikit ini juga dibuktikan dengan adanya nilai mean infit dan outfit ZSTD yang negatif, berdasarkan pernyataan Bond \& Fox (2015), "Angka negatif pada infit dan outfit ZSTD menandakan variasi jawaban yang lebih sedikit." 


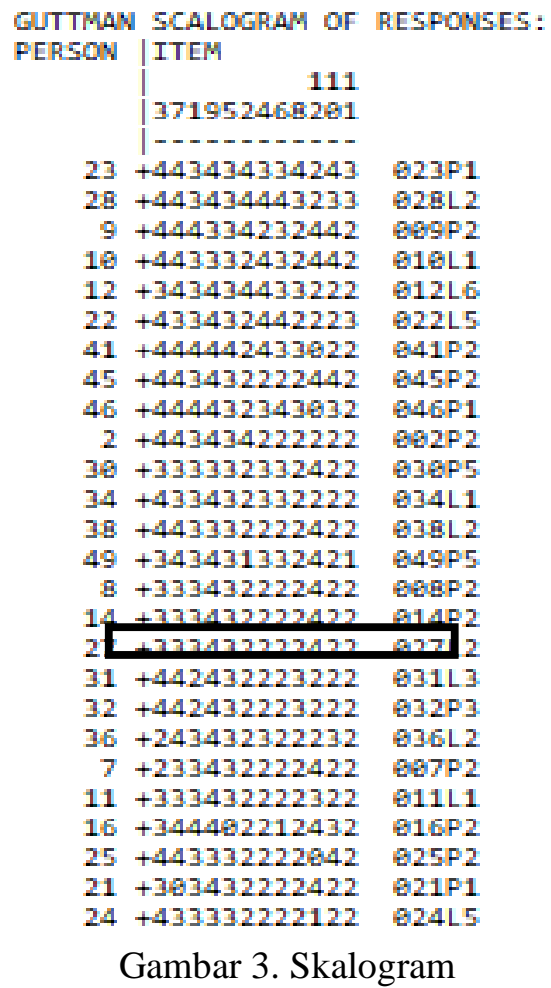

Gambar 3 merupakan skalogram yang menggambarkan respon person atau item yang mana item-item tersebut diurutkan tingkat kesulitannya dari kiri ke kanan (paling mudah ke paling susah), serta subjek yang diurutkan berdasarkan kemampuannya dari atas ke bawah (tinggi ke rendah) (Bond \& Fox, 2015). Melalui Gambar 3 diketahui terdapat lima subjek yang memiliki pola jawaban tes yang sama, di antaranya adalah subjek 008P2; 014P2; dan 027L2, serta 031L3 dan 032P3 sehingga terdapat kemungkinan peserta didik tersebut bekerja sama dalam mengerjakan tes literasi kimia.

3) Reliabilitas person, berdasarkan data penelitian, diketahui nilai reliabilitas person yang didapat adalah 0,86 hal ini menunjukkan bahwa konsistensi jawaban dari subjek penelitian terhadap instrumen yang diberikan sudah baik (good).

4) Wright map, hasil dari pendistribusian kemampuan literasi kimia peserta didik kelas XI MIPA di SMAN 1 Batam TA 2020/2021 dapat dilihat pada Gambar 4.

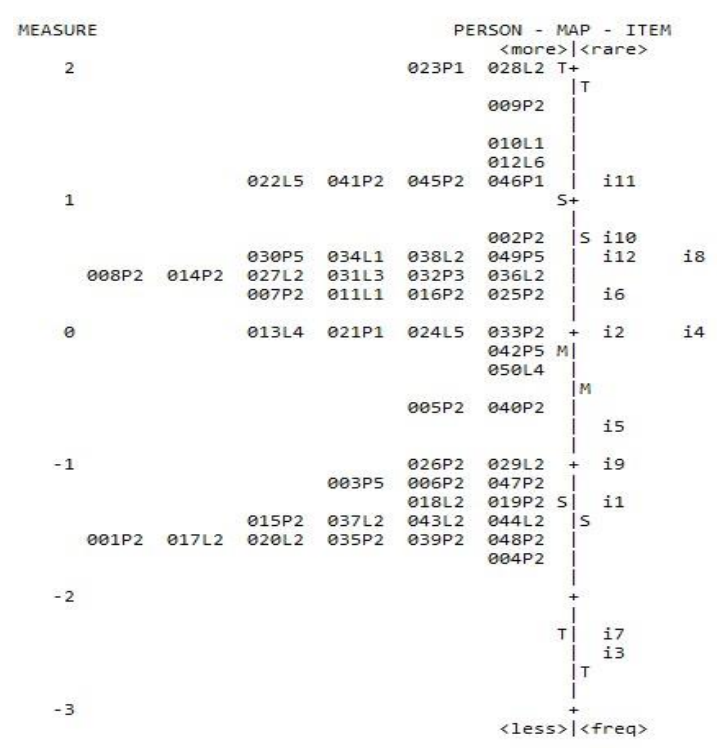

Gambar 4. Wright Map

Pada bagian sebelah kiri Wright map merupakan peta kemampuan person, dalam skala logit. Sementara bagian sebelah kanan Wright map merupakan tingkat kesulitan item tes. Item yang mudah, terletak pada bagian dasar Wright map dan item yang sulit terletak pada bagian puncak Wright map, person dengan kemampuan yang rendah terletak pada bagian dasar, sementara person dengan kemampuan yang tinggi terletak pada bagian puncak Wright map.

Analisis Wright map yang didapatkan adalah, Subjek dengan nomor identitas 023P1 dan 028L2 merupakan subjek yang memiliki literasi kimia paling tinggi pada butir soal yang paling sulit (i11), yaitu pada tingkat conceptual scientific literacy, sementara subjek dengan nomor identitas 004P2 merupakan subjek dengan kemampuan literasi kimia yang paling rendah pada i11, yaitu pada tingkat scientific illiteracy.

Subjek 023P1 dan 028L2 memiliki nilai measure yang sama $(+2,47$ logit) artinya kedua subjek memiliki kemampuan literasi kimia yang sama. Nilai logit di atas +2 menandakan subjek memiliki kemampuan yang baik, logit +1 menandakan subjek memiliki kemampuan menengah, dan logit -1 menandakan subjek memiliki kemampuan yang rendah (Ibnu dkk., 2019)

Literasi kimia merupakan bagian dari literasi sains (Rahayu, 2017) yang termasuk pada keterampilan abad ke-21 dan diperlukan oleh peserta didik (World Economic Forum, 2015). 
Penelitian analisis literasi kimia peserta didik kelas XI MIPA di SMAN 1 Batam TA 2020/2021 mendominasi skor 2 pada tes literasi kimia. Skor 2 didapatkan karena jawaban peserta didik yang benar namun masih terdapat keterbatasan dalam penjelasan jawaban butir soal tes tersebut.

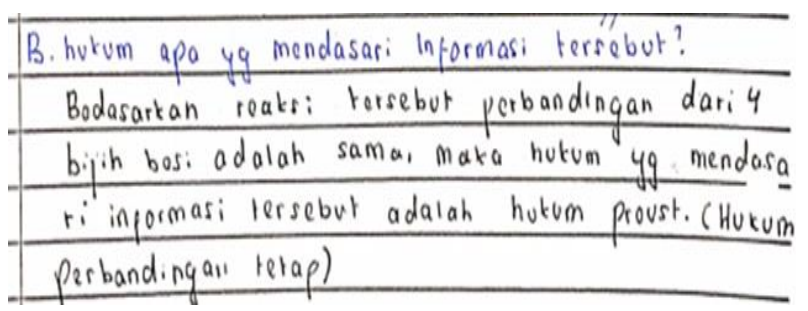

Gambar 5. Contoh Analisis Jawaban Peserta Didik

Melalui Gambar 5 diketahui jawaban peserta didik adalah benar, namun penjelasan jawaban masih sangat terbatas, hal yang dibandingkan dari bijih besi tidak dijelaskan, selain itu jawaban yang dituliskan tidak dihubungkan dengan teks wacana yang diberikan.

Berdasarkan Wright map, diketahui subjek dengan kemampuan tertinggi memiliki literasi kimia pada butir soal paling sulit ditingkat conceptual scientific literacy, sementara subjek dengan kemampuan terendah tidak memiliki kemampuan literasi kimia atau disebut sebagai $s c i$ entific illiteracy.

Perolehan tingkat literasi kimia tersebut dipengaruhi dengan adanya ketidakpahaman peserta didik terhadap materi hukum-hukum dasar kimia yang telah dipelajari saat mereka berada di kelas $X$, hal ini sesuai dengan hasil survei yang dilakukan terhadap peserta didik kelas XI MIPA di SMAN 1 Batam.

Hasil penelitian Shwartz dkk., (2006) mendukung hasil penelitian ini, yaitu: "Pembelajaran topik dasar pada kimia memberikan kontribusi yang penting pada tingkat literasi kimia peserta didik." Hasil penelitian ini juga mendukung pendapat Yakmaci-Guzel (2013), yaitu, kimia memiliki konsep yang abstrak, sehingga peserta didik harus lebih bersemangat dalam mempelajari konsep hukum-hukum dasar kimia agar pemahaman peserta didik dalam topik tersebut semakin baik dan memberikan dampak yang baik terhadap tingkat literasi kimia peserta didik. Selain itu, ini adalah kali pertama peserta didik kelas XI MIPA di SMAN 1 Batam TA 2020/2021 mengerjakan soal berbasis literasi kimia, sehingga pernyataan Odja \& Payu (2017), yaitu: "Pada umumnya peserta didik yang belum terbiasa mengerjakan tes keterampilan proses sains memiliki kemampuan literasi sains yang cenderung rendah" juga mendukung hasil penelitian ini.

\section{KESIMPULAN}

Pemahaman konsep peserta didik kelas XI MIPA di SMAN 1 Batam pada topik hukumhukum dasar kimia sangat mempengaruhi literasi kimia peserta didik. Berdasarkan hasil analisis data, literasi kimia peserta didik dengan kemampuan paling tinggi pada soal sulit adalah pada conceptual scientific literacy, sementara peserta didik dengan kemampuan paling rendah pada butir soal yang sama tidak memiliki kemampuan literasi kimia (scientific illiteracy). Agar literasi kimia peserta didik dapat ditingkatkan, disarankan untuk dilakukan penelitian mengenai model, metode, dan media pembelajaran yang dapat diimplementasikan untuk meningkatkan literasi kimia peserta didik.

\section{DAFTAR PUSTAKA}

Bond, T. G., \& Fox, C. M. (2015). Applying the Rasch Model Fundamental Measurement in the Human Sciences (Third Edit). Routledge.

Boone, W. J., Staver, J. R., \& Yale, M. S. (2014). Rasch Analysis in the Human Sciences. Springer.

Furwana, D. (2019). Validity and Reliability of Teacher-Made English Summative Test at Second Grade of Vocational High School 2 Palopo. Language Circle: Journal of Language and Literature, 13(2).

Ibnu, M., Indriyani, B., Inayatullah, H., \& Guntara, Y. (2019). Aplikasi Rasch Model: Pengembangan Instrumen Tes untuk Mengukur Miskonsepsi Mahasiswa. Prosiding Seminar Nasional Pendidikan FKIP, 2(1), 205-210.

Imansari, M., Sudarmin, \& Sumarni, W. (2018). Analisis Literasi Kimia Peserta Didik melalui Pembelajaran Inkuiri Terbimbing Bermuatan Etnosains. Jurnal Inovasi Pendidikan Kimia, 12(2), 2201-2211.

Kemendikbud. (2018). Peraturan Menteri Pendidikan dan Kebudayaan Nomor 36 Tahun 2018 tentang Perubahan atas 
Peraturan Menteri Pendidikan dan Kebudayaan Nomor 59 Tahun 2014 tentang Kurikulum 2013 Sekolah Menengah Atas/Madrasah Aliyah. Permendikbud. jdih.kemdikbud.go.id

Khine, M. S. (2020). Rasch Measurement Application in Quantitative Educational Research (M. S. Khine (ed.)). Springer.

Lestari, A. S., \& Samsudin, A. (2020). Using Rasch Model Analysis to Analyze Students' Scientific Literacy on Heat and Temperature. Proceedings of the 7th Mathemnatics, Science, and Computer Science Education International Seminar.

Muhammad, S. N., Listiani, \& Adhani, A. (2018). Kemampuan Literasi Sains Siswa pada Materi Ekosistem di SMA Negeri 3 Tarakan Kalimantan Utara. QUANTUM: Jurnal Inovasi Pendidikan Sains, 9(2), 115120.

Odja, A. H., \& Payu, C. S. (2017). Analisis Kemampuan Awal Literasi Sains Mahasiswa Pada Konsep IPA. Education and Human Development Journal, 1(1), 40-47.

OECD. (2015). PISA 2015 Draft Science Framework (Issue March 2013).

Rahayu, S. (2017). Mengoptimalkan Aspek Literasi dalam Pembelajaran Kimia Abad 21. Prosiding Seminar Nasional Kimia UNY 2017, 21, 1-16.

Sartika, A. Y. M., \& Yusmaita, E. (2020). Pengembangan Asesmen Literasi Kimia pada Materi Hukum-Hukum Dasar Kimia dan Stoikiometri Kelas X SMA/MA. Edukimia, 2(3), 128-133.

Shwartz, Y., Ben-Zvi, R., \& Hofstein, A. (2006). The Use of Scientific Literacy Taxonomy for Assessing the Development of Chemical Literacy among High-school Students. Chemistry Education Research and Practice, 7(4), 203-225.

Sumintono, B., \& Widhiarso, W. (2015). Aplikasi Pemodelan Rasch pada Assessment. Trim Komunikata Publishing House.

Thummathong, R., \& Thathong, K. (2016). Construction of a Chemical Literacy Test for Engineering Students. Journal of Turkish Science Education, 13(3), 185-198.

Thummathong, R., \& Thathong, K. (2018). Chemical Literacy Levels of Engineering Students in Northeastern Thailand. Kasetsart Journal of Social Sciences, 39(3),
$478-487$.

Untary, H., Risdianto, E., \& Kusen. (2020). Analisis Data Penelitian dengan Model Rasch dan Winsteps. Halaman Moeka Publishing.

World Economic Forum. (2015). New Vision for Education: Unlocking the Potential of the Smart Grid. AIP Conference Proceedings, 1702.

Yakmaci-Guzel, B. (2013). Preservice chemistry teachers in action: An evaluation of attempts for changing high school students' chemistry misconceptions into more scientific conceptions. Chemistry Education Research and Practice, 14(1), 95-104. 